\title{
Espaço, poder e escravidão no De Re Rustica de Columela*
}

Fábio Duarte Joly

Doutorando/USP

RESUMO

Este artigo analisa a configuração do espaço e a organização do trabalho escravo na propriedade rural (uilla) descrita por Columela em seu tratado De Re Rustica, tendo como hipótese que ambos os aspectos não são regidos por critérios exclusivamente econômicos, como a historiografia geralmente entende, mas sobretudo políticos, uma vez que remetem ao entendimento que Columela tinha da política romana na época do principado de Nero. Palavras-chave: Roma; escravidão; Columela.

INTRODUÇÃO

\begin{abstract}
This article examines the space configuration and the organization of slave work in the rural property (uilla) as described by Columela in his treaty $\mathrm{De} R e$ Rustica. The related hypothesis is that both aspects are not solely governed by financial criteria, as historiography usually perceives, but also political, given it refers to Columela's understanding of Roman politics during Nero's principality.
\end{abstract}

Keywords: Rome; slavery; Columela.

A partir do final do século XV, quando manuscritos medievais, contendo obras de escritores gregos e romanos, começaram a ser redescobertos e valorizados, seu estudo levou obviamente a comparações entre o presente e o passado, com uma clara inclinação positiva para esse último. O Renascimento europeu elevou a cultura grega e romana a um exemplo de perfeição e de medida, uma imagem que iria perdurar inabalável até pelo menos o século XVIII. "É prerrogativa dos antigos não fazer nada nem de mais nem de menos”, escreveu Lessing no prefácio ao seu Laocoonte ou Sobre as Fronteiras da Pintura e da Poesia ${ }^{1}$. E isso não apenas no campo da arte. Na esfera da política fez-se sentir a leitura de historiadores latinos, como Salústio, Tito Lívio e Tácito, e de filósofos gregos, como Aristóteles e Platão, então mencionados pelos humanistas como fontes de ensinamentos para a ação política e para a análise dos sistemas de governo. De um certo modo, portanto, o nascimento do vocabulário político moderno esteve relacionado a essa retomada da tra- 
dição greco-romana. Palavras como tirania, democracia, aristocracia e império, retiradas dos clássicos, serviram como conceitos para se pensar na realidade contemporânea.

No campo da economia uma semelhante recepção ocorreu e teve nos denominados "agrônomos latinos" - Catão, Varrão e Columela — o seu foco de interesse. Embora tenham escrito em épocas diversas, suas obras foram geralmente publicadas em conjunto, constituindo como que "um padrão de escrito agrícola na Europa Ocidental e no seu universo colonial”" Nesse momento de formação de uma literatura agronômica na Europa e colônias, os citados escritores latinos serviram como um manancial de preceitos práticos sobre a administração da propriedade e da mão-de-obra escrava, entre diversos procedimentos agrícolas mencionados. Tal leitura predominantemente econômica desse corpus documental arraigou-se na historiografia sobre a economia romana, que a partir do século XIX começou a ganhar corpo e que ainda hoje se serve dos escritos de Catão, Varrão e Columela para discutir a produtividade do trabalho escravo, a organização do trabalho na uilla e o destino da produção. Essas questões, em última instância, desembocam no tema mais amplo da racionalidade econômica na Antigüidade e seus respectivos limites diante da economia capitalista moderna.

Devido a essa óptica que vê na uilla uma organização essencialmente econômica, bem testemunhada pela querela entre modernistas e primitivistas, outras possibilidades de leitura dos agrônomos latinos foram deixadas em segundo plano. Decerto que a produção agrícola e pastoril é o pressuposto da composição dessas obras, mas disso não decorre a priori que critérios exclusivamente econômicos regeram as concepções de organização do espaço e da mão-de-obra no interior da propriedade. Nesse sentido, o presente ensaio apresenta uma análise alternativa das obras agronômicas latinas, sustentando que critérios de ordem política influenciaram tanto a distribuição espacial como a gestão escravista na uilla. Para tanto, centraremo-nos na obra de Columela, De Re Rustica, concebida nos marcos do principado de Nero, sendo que a hipótese que nos servirá de guia é a de que, no período imperial romano, concomitantemente à concentração de poder nas mãos do imperador e ao conseqüente declínio do poder e do prestígio da aristocracia no campo político, assiste-se a uma tentativa de parte dessa mesma aristocracia de restaurá-los no campo doméstico. Daí as comparações entre domus e res publica que, no caso de Columela, leva-o a desenhar a uilla ideal como um pequeno Estado, em cujo topo está o proprietário na figura de um "imperador".

Tendo em vista esse propósito, a exposição divide-se em duas partes. Inicialmente, após uma breve apresentação de Columela e sua obra, buscar-se-á expor em suas linhas gerais as perspectivas de análise que a historiografia moderna tem aplicado à obra columeliana. Em seguida, passar-se-á à análise da 
fonte propriamente dita a fim de indicar as inter-relações entre espaço, poder e escravidão na uilla concebida por Columela, de acordo com a hipótese acima levantada.

\section{COlUMEla: TeÓRICO DE UMA ECONOMIA EsCRAVISTA?}

Sobre Columela (Lucius Moderatus Columella) pouco sabemos. Embora não seja possível determinar os anos de seu nascimento e morte, é certo que viveu na época do principado neroniano (54-68 d.C.), sendo originário da província da Bética, mais precisamente de Gades. Essa datação provém das menções que faz ao filósofo Sêneca e às propriedades deste na região de Nomento (De R. R., III, 3,2), bem como a outros personagens do círculo de amizades de Sêneca, como Júnio Gálio e M. Trebélio Máximo (De R. R., V, 1, 2; IX, 16, 2) ${ }^{3}$. Este último pode ser o legado sob o qual, em 36 , Columela serviu como tribuno militar na legião VI Ferrata, estacionada na Síria. Uma inscrição descoberta em 1685 em Tarento, e hoje perdida, atesta esse cargo ${ }^{4}$. Columela representa então uma aristocracia provincial que ganhava espaço em Roma e que tinha seguramente em suas propriedades fundiárias uma fonte de renda. Na Itália, Columela possuía terras em pelo menos quatro regiões: perto de Caeres na Toscana, nas proximidades de Carsioli no Lácio, na região de Alba e uma última nos arredores de Ardea ${ }^{5}$.

Quanto à sua produção intelectual, cabe notar de início que, à diferença de Catão e Varrão, Columela não compôs sobre os mais diversos campos da cultura, embora demonstre conhecimento de poesia, sobretudo Virgílio, e de filosofia, particularmente na sua vertente estóica. Além de um escrito sobre astrologia (cf. De R. R., XI, 1, 31: iis libris quos contra astrologos composueram), que não se conservou, sua obra resume-se a um tratado agronômico em doze livros. É um especialista, portanto, dado que por si só já indica como se configurava a cosmovisão de parte da aristocracia imperial no período júlio-cláudio.

Os livros de seu tratado, com exceção do livro 11, endereçado a Cláudio Augustal, têm por destinatário P. Silvino, mas de ambos não temos informações. O livro 1 traz uma introdução geral e disserta sobre o problema da gestão da propriedade. O livro 2 versa sobre o plantio de cereais e leguminosas. Os livros 3, 4 e o início do 5 tratam da viticultura, e, ao final do 5, Columela volta-se para a arboricultura. Os livros 6 a 9 tecem considerações sobre a criação de animais. O livro 10 é escrito em versos, um poema sobre jardins. No livro 11 Columela detém-se nas funções do capataz da uilla, o uilicus, e no tema da horticultura. Por fim, o livro 12 considera as atribuições da uilica, esposa do capataz, e traz algumas receitas diversas.

Interessa-nos sobretudo os livros 1 e 11 pois neles melhor se delineia a 
concepção que Columela tem do espaço e da distribuição do poder na propriedade agrícola. Suas idéias sobre esses pontos vem sendo já há um bom tempo abordadas pela bibliografia moderna e, por conseguinte, convém apresentar de forma resumida o debate em torno das visões econômicas de Columela, uma vez que se tende a apresentá-lo como um teórico da economia escravista italiana dos primeiros séculos do império.

Deve-se a Herman Gummerus ${ }^{6}$ a introdução dos agrônomos latinos, e portanto de Columela, no debate sobre a economia antiga em curso a partir da segunda metade do século XIX na Alemanha, e que teve como seus principais representantes Karl Bücher, Eduard Meyer e Max Weber. Escrevendo no início do século XX, Gummerus contrapunha-se à tese formulada por Bücher de que na Antigüidade teria predominado uma "economia doméstica fechada" (geschlossene Hauswirtschaft), cuja mão-de-obra utilizada era exclusivamente servil, tese que aliás retomava o conceito de "economia do oikos" proposto por Rodbertus, que caracterizava a Antigüidade como um período no qual predominava a economia de unidades domésticas autônomas, sendo o comércio apenas eventual e esporádico. Na opinião de Gummerus, os dados fornecidos pelos agrônomos latinos permitiam refutar essa imagem, uma vez que em suas obras mencionam outras formas de exploração do trabalho além da escravidão e apresentam a propriedade agrícola não como um espaço fechado em si mesmo, mas em íntima conexão com centros urbanos de produção que comerciavam produtos que essas propriedades não podiam fabricar. Atualmente esses pontos já são bastante evidentes para que se continue a enfatizá- $\operatorname{los}^{7}$, mas ainda permanece a controvérsia sobre o modo como se configura a racionalidade econômica nos escritos dos agrônomos, no sentido de sua maior ou menor aproximação com uma racionalidade capitalista.

Por exemplo, enquanto Gummerus vincula sem ressalvas escravidão e capitalismo ${ }^{8}$, Max Weber busca nuançar tal relação na segunda edição de sua obra Relações Agrárias na Antigüidade, de 1909. Para Weber, o uso capitalista do trabalho escravo difere substancialmente do emprego do trabalho livre por necessitar de maior disponibilidade de capital (para a compra de escravos), por estar à mercê da mortalidade dos cativos e da oscilação dos preços, o que impede um cálculo seguro da empresa escravista, e, por fim, por depender de um mercado de escravos continuamente reabastecido por guerras 9 . O pressuposto dessa crítica do sistema escravista é de que uma das condições prévias para a existência de empresas capitalistas no sentido moderno do termo é o trabalho livre, pois apenas este possibilita um cálculo racional do capital, ou seja, os custos dos produtos podem ser calculados de antemão ${ }^{10}$.

Essa perspectiva de análise que julga a racionalidade econômica antiga em comparação com o que seria uma racionalidade capitalista desdobrou-se 
posteriormente na historiografia sobre a economia romana, que muitas vezes toma Weber como referência. Assim, para a denominada Escola de Cambridge, inaugurada por M. I. Finley e continuada por seus discípulos, como Richard Saller e Peter Garnsey, não houve propriamente uma racionalidade econômica nos moldes daquela presente no mundo contemporâneo devido a fatores estruturais, como o estágio pouco avançado das trocas mercantis e do desenvolvimento tecnológico na agricultura, e mentais, como a ausência de uma "ética capitalista" que permitisse a aplicação do lucro no comércio e não apenas na aquisição de terras, o que revelava uma cosmovisão essencialmente aristocrática. Diante desse quadro, qualquer possibilidade de mudança é descartada e a economia romana aparece como estática ou mesmo como "subdesenvolvida", nos termos de Saller e Garnsey ${ }^{11}$. Finley, por sua vez, a quem devemos em grande parte a elaboração dessa óptica, mencionando Columela, resume a questão do seguinte modo:

Não duvido que Columela, por exemplo, apesar das suas limitações, podia ter feito a simples computação aritmética necessária para revelar as economias possíveis de uma escala de exploração alargada. Por outras palavras, não se tratava de uma questão intelectual. [...] A poderosa influência da unidade doméstica camponesa, as atitudes em relação ao trabalho e à administração, o fraco mercado urbano, os lucros satisfatórios do regime agrícola existente, talvez as dificuldades inerentes à organização e administração de uma força de escravos muito grande - tudo servia para desencorajar a mudanç $\mathrm{a}^{12}$.

Por outro lado, a historiografia marxista italiana contesta essa posição. De acordo com Norberto Guarinello, para essa corrente, em que se destaca Andrea Carandini, "a 'uilla escravista', reconhecível nas 'descrições' dos escritores agrários, teria sido [...] o verdadeiro motor da economia romana entre os séculos II a.C. e II d.C., introduzindo novas formas de cooperação e especialização do trabalho escravo e voltando-se decididamente para a produção mercantil destinada, sobretudo, aos mercados do Ocidente romano. Essa combinação de escravidão com uma produção intensiva e com fins lucrativos comporia o que Carandini denominou de um 'caso de desenvolvimento pré-capitalista"'13. No que concerne especificamente a Columela, Carandini combate frontalmente a interpretação de Finley, interpretando-a como resultado de uma apologia do mundo moderno e contrapondo-lhe uma interpretação fundada na idéia de bissetorialidade — tomada das reflexões de Witold Kula sobre as propriedades agrícolas na Polônia medieval — da uilla, que seria assim composta por dois setores, um natural, voltado para a subsistência da própria fazenda, e outro mercantil, direcionado para o mercado ${ }^{14}$. E, nesse último sentido, a uilla columelia- 
na torna-se, para Carandini, o tipo ideal da propriedade vinícola da Itália do século I d.C., momento em que se teria tornado necessário a remodelação da produção para enfrentar a concorrência das províncias ${ }^{15}$.

No tocante ao tema da organização do trabalho escravo, como abordado por Columela, a historiografia acima citada entende-o obviamente como diretamente vinculado à questão da produtividade da uilla e, de fato, o próprio Columela deixa claro que seu tratado tem por objetivo instruir aqueles que desejam obter uma renda de suas propriedades agrícolas (I, Praef., 7) e que o primeiro passo para tal é cuidar da escolha da escravaria. Mas o que sua obra também deixa entrever é uma leitura política dessa questão no sentido de que a configuração das relações escravistas na uilla columeliana relaciona-se ao modo como determinada parcela da aristocracia visualizava sua posição política na Roma imperial.

Alguns estudiosos já observaram que a obra de Columela poderia ter originalmente um viés político. Assim, por exemplo, para René Martin, Columela, representando uma "burguesia italiana" e também provincial, era o porta-voz de um grupo de proprietários de terras, que no período júlio-cláudio buscava afirmar-se economicamente diante de categorias sociais que então ascendiam, como os libertos e comerciantes. Para tanto, advogava uma agricultura intensiva, especializada na viticultura, opondo-se ao modelo propugnado pelo grupo dos proprietários latifundiários - uma aristocracia senatorial romana de velha estirpe - que praticava a criação extensiva e cuja fortuna, mesmo se alocada para as propriedades fundiárias, era de origem não agrícola. Ademais, quando transposto para um plano filosófico, esse embate aparecia como uma oposição entre o epicurismo e sua tese da esterilidade natural e progressiva do solo, combatida por Columela, e o estoicismo, que enfatiza o trabalho humano como capaz de transformar a natureza ${ }^{16}$. Por seu turno, a esses modelos econômicos distintos correspondiam diferentes formas de se pensar no emprego do trabalho escravo. No caso das grandes propriedades admitia-se, diante do absenteísmo do proprietário, relegar aos escravos toda a gestão do trabalho agrícola, independentemente de suas qualidades técnicas. Para Columela, pelo contrário, ainda que aceite a inevitabilidade do absenteísmo, a preocupação recai fundamentalmente sobre a qualificação da mão-de-obra empregada.

Logo, é preciso então melhor especificar como Columela situa-se na sociedade de seu tempo e como ele delimita seus objetivos tendo em mente um determinado público leitor. Já mencionamos acima alguns desses aspectos, mas agora procuraremos especificá-los no próprio texto. Torna-se então elucidativo o prefácio do seu De Re Rustica, onde logo de início define quem seria seu público: 
Freqüentemente ouço os que são proeminentes em nossa cidade ora condenando a infecundidade dos campos, ora a intempérie do céu há tempos prejudicial às colheitas; outros ainda, como que com razão, abrandando essas queixas, crêem que o solo cansou-se e exauriu-se com a pujança dos tempos passados, a ponto de não mais poder oferecer alimentos aos mortais com a bondade de outrora. (I, Praef., 1$)^{17}$

Neste trecho evidencia-se o caráter político do tratado de Columela. Ele é uma resposta à ideologia predominante no interior de um grupo político de peso não desprezível na condução do Estado romano (como demonstra o termo ciuitatis nostrae principes). A conseqüência dessa postura o autor coloca logo em seguida, quando afirma que, por pensarem assim, tais indivíduos deixam a agricultura a cargo dos "piores dentre os escravos" (pessimo cuique seruorum, I, Praef., 3). Logo, Columela estabelece uma correlação entre status político e uma determinada forma de emprego do trabalho escravo na época em que escreve, isto é, na primeira metade do século I: quanto maior o status, maior o desprezo às atividades agrícolas e, por conseguinte, maior o uso indiscriminado de escravos. Para realçar essa prática da aristocracia Columela utiliza como espelho uma idealização do passado republicano, quando teria sido comum os homens públicos alternarem o exercício da política e da guerra com o cultivo de seus próprios campos (I, Praef., 13-14). Esse quadro é utilizado como contraponto para traçar as características da aristocracia de seu tempo que, de acordo com Columela, passava os dias em um ócio desregrado e licencioso (I, Praef., 16-17). Ademais, essa aristocracia desprezava as possibilidades de ganho que a agricultura poderia proporcionar, além de ser uma atividade mais condizente com a justiça do que a guerra, o comércio marítimo, o empréstimo a juros e, sobretudo, do que a montagem de uma rede de relações de amizade e patronato com indivíduos mais poderosos com o intuito de obter vantagens materiais ou cargos. A crítica de Columela recai sobremaneira nesse último ponto:

Devo julgar mais honrada a falsa perseguição daquele que presta saudação por dinheiro, rodeando as casas dos poderosos e auscultando os ruídos do sono de seu rei? Pois nem se perguntados, os escravos dignam-se a responder-lhe o que se passa dentro. Ou devo julgar mais afortunado aquele que toda a noite, repelido por um escravo acorrentado à entrada, atira-se a portas ingratas, e pelo mais miserável servilismo, à custa de sua honra, negocia a honra e o poder dos fasces, também despendendo seu patrimônio? Pois não é com uma escravidão voluntária, mas com bens que a honra é comprada. Se de tais coisas e similares os homens bons devem fugir, resta, como disse, um modo liberal e digno de um homem livre de aumentar as posses familiares, e este reside na agricultura. (I, Praef., 9-10) 
Fábio Duarte Joly

Columela apresenta então a agricultura não apenas como uma atividade capaz de gerar uma renda qualquer, mas que possibilita uma vida digna de um homem livre no sentido estóico do termo, ou melhor, daquele que não tem sua liberdade coagida pela busca incessante de bens materiais. Por outro lado, a relação entre status político e escravidão reaparece no trecho acima sob a forma metafórica e que também guarda contato com o estoicismo. Columela, ao comparar aquele que busca ascender na carreira política a um escravo, tem em mente a distinção estóica entre liberdade e escravidão jurídicas e liberdade e escravidão morais e sua não necessária coincidência. Nesse ponto Columela concorda com Sêneca, de quem era contemporâneo e provavelmente ligado por relações de amizade. Para o filósofo, a condição sociopolítica de um indivíduo e, conseqüentemente, a valoração social da mesma é algo arbitrário (Epistulae Morales 31, 11; De Beneficiis III, 18). O que importa é a conduta adotada em vida e, nesse sentido, há livres que se comportam como escravos e vice-versa.

Dessa definição da agricultura como uma atividade que confere independência a quem a pratica depreende-se que o objetivo do tratado de Columela não se situa exclusivamente no campo econômico, mas também no campo político e moral. Ao sugerir que a propriedade agrícola pode ser um refúgio diante das coerções do círculo do poder na Roma imperial, Columela deixa transparecer que escreve para um público que não mais detém prestígio e poder político comparáveis ao do período republicano que ele enaltece, com sua figura do aristocrata-agricultor, seguro de sua posição política na urbe. O prefácio da obra de Columela apresenta uma sociedade em que a competição política é canalizada por uma rede de relações de patronato e amizade, o que, por sua vez, torna instável a posição sociopolítica dos indivíduos, pois muitas vezes rebaixa-os a uma condição de inferioridade hierárquica, se não de fato, pelo menos no campo moral, como demonstra o uso da metáfora da escravidão. A mesma instabilidade Columela observa nas outras formas de obtenção de renda, como o comércio marítimo, a guerra e a usura, o primeiro pela própria imprevisibilidade da natureza, os outros dois pelo conflito social que engendram.

A uilla aparece então como um espaço que pode corrigir a instabilidade econômica e política de uma elite que, pela própria estrutura do Principado, com o monopólio do poder pelo imperador, encontrava-se em uma posição subalterna. Como será analisado a seguir, nesse contexto joga um papel primordial a instituição da escravidão. Por um lado, fornece a mão-de-obra principal para as atividades agrícolas e pastoris; por outro, faz parte de uma estrutura de relações de poder em que o proprietário encontra-se absoluto no topo. Columela não é portanto apenas o teórico de uma economia escravista 
stricto sensu (até porque isto seria impossível antes da autonomização do discurso econômico), mas de uma política da escravidão.

\section{EsPaço e Poder na Villa Columeliana}

Discutir a relação entre espaço e poder significa abordar a questão do modo como as formas produzidas por uma sociedade reproduzem as relações entre os indivíduos nessa mesma sociedade. No caso da uilla descrita por Columela, essa problemática aparece logo no primeiro livro do De Re Rusti$c a$, em que são abordadas a distribuição espacial da propriedade e sua respectiva hierarquia de poder.

Columela divide a uilla em três partes: urbana (pars urbana), rústica (pars rustica) e aquela relativa à produção agrícola (pars fructuaria) $(\mathrm{I}, 6,1)$. A parte urbana é onde reside o proprietário. Nas palavras de Columela:

A parte urbana, por sua vez, divide-se em aposentos de inverno e de verão, de modo que os quartos de inverno voltem-se ao oriente no solstício de inverno e as salas de refeições ao ocidente no equinócio. Por outro lado, os aposentos de verão voltam-se para o sol de meio-dia no equinócio, mas as salas de refeições desse tempo voltam-se para o oriente no inverno. Os banhos devem orientar-se para o ocidente no verão, a fim de que sejam iluminados após o meio-dia até à tarde. Os passeios devem estar expostos ao sol de meio-dia no equinócio, para no inverno receber o máximo de sol e no verão o mínimo. (I, 6, 1-2)

Como se vê, a orientação da construção segue critérios estritamente climáticos. Nada na descrição sugere princípios hierárquicos entre os aposentos, prevalecendo a idéia de livre circulação entre eles. Apesar de Columela conceber a parte urbana da uilla obviamente em comparação com as residências da aristocracia em Roma, há um claro contraste, por exemplo, com a descrição vitruviana dessas últimas, que ressalta a relação entre as diferentes categorias sociais e o espaços a elas reservados nas domus $^{18}$. Por outro lado, na descrição da pars rustica, esse ponto já se faz notar:

Na parte rústica há que se ter uma grande e alta cozinha, para que as vigas de madeira estejam livres do perigo de incêndio, e para que nela os escravos possam comodamente ficar durante todas as épocas do ano. É melhor que os quartos para os escravos soltos sejam feitos voltados para o sol de meio-dia no equinócio; para os acorrentados deve-se ter um ergástulo o mais saudável possível, com muitas e estreitas janelas para iluminar, mas distantes do solo para não serem alcançadas pela mão. $(\mathrm{I}, 6,3)$ 
Existem, portanto, duas categorias de escravos e conseqüentemente dois espaços que lhes cabem. As cellae - provavelmente pequenos quartos no interior de uma construção maior ${ }^{19}$ - abrigam os escravos que não ficam acorrentados nas horas vagas, enquanto os demais permanecem no ergastulum. Por sua vez, espaços específicos são destinados ao procurator e ao capataz, o uilicus, encarregados da supervisão da mão-de-obra e do funcionamento da uilla:

Para o capataz a habitação deve ser feita próxima da porta para que possa observar quem entra ou sai. Para o procurador deve ser feita acima da porta pelos mesmos motivos e para que observe de perto o capataz. Perto de ambos há o celeiro, onde se guardam todos os instrumentos agrícolas; e dentro dele há um local fechado para reunir as ferramentas. (I, 6, 7)

A distribuição espacial desses aposentos segue assim claros critérios hierárquicos. $\mathrm{O}$ uilicus deve situar-se de modo a poder observar a movimentação de pessoas na propriedade e daí localizar-se perto da entrada da uilla. Já a habitação do procurator - em posição hierárquica superior à do uilicus situa-se conseqüentemente acima daquela do uilicus, para supervisioná-lo e ao restante da propriedade. Do mesmo modo, os escravos responsáveis pelo cuidado dos animais devem residir adjacente aos estábulos e de maneira a também facilitar o controle pelo uilicus:

Os quartos dos pastores devem estar ao lado de seus rebanhos para que possam cuidar deles quando seja preciso. E todos devem morar o mais próximo possível entre si, para que o empenho do capataz não se desdobre para circular por diversos lugares e para que entre eles a diligência e a negligência de cada um esteja aparente. $(\mathrm{I}, 6,8)$

Por fim, a pars rustica engloba ainda os estábulos (de verão e de inverno) $(I, 6,4)$ e um armazém para guarda dos instrumentos agrícolas (I, 6, 7). A pars fructuaria (I, 6, 9-20) compreende as construções destinadas à produção de vinho e azeite e ao armazenamento de trigo. Inclui-se nela também uma área de banho para os escravos.

Logo, a organização do espaço na uilla columeliana repete a distribuição do poder entre seus agentes. Na pars urbana, o proprietário naturalmente não está sujeito a quaisquer restrições de circulação. Já na pars rustica os espaços são atribuídos de acordo com o grau de subordinação dos trabalhadores. No entanto, para melhor compreender tal fenômeno, é preciso nos determos mais longamente nas atribuições de cada agente na uilla, principalmente no que tange ao proprietário (dominus, paterfamilias), ao uilicus e demais escravos.

O tipo de proprietário que Columela tem em mente ao descrever a uilla 
deriva da maneira como concebe a gestão da propriedade. Como aponta René Martin, há uma hierarquia de modos de gestão no De Re Rustica. O modo ideal seria aquele em que o proprietário administrasse pessoalmente o seu domínio, residindo no local. Em segundo lugar está o modo de gestão por meio de um uilicus, mas sob supervisão do proprietário. Em terceiro lugar, um sistema de arrendamento, quando se tratar de propriedades muito distantes. Por fim, a exploração do domínio mediante um uilicus, mas sem qualquer interferência do proprietário ${ }^{20}$. O segundo modo é o desenvolvido por Columela, visto que reconhece a impossibilidade de uma residência permanente do proprietário (I, 2, 1).

Daí decorre a importância da figura do uilicus (e também da uilica, sua companheira) na obra columeliana, o que a torna única se comparada às obras de Catão e Varrão, que mencionam esse personagem mas não de maneira tão enfática. Para Columela, o uilicus "toma o lugar do senhor" na uilla, assim como a uilica substitui a senhora (Quam ob causam cum in totum non solum exoleuerit, sed etiam occiderit uetus ille matrumfamiliarum mos Sabinarum atque Romanarum, necessaria irrepsit uillicae cura, quae tueretur officia matronae: quoniam uilicus sucesserunt in locum dominorum, XII, 1, 10). Logo, as qualidades do uilicus devem ser o trabalho e a experiência (labor et experientia uilici) (I, 1, 18). Ele não deve jamais abandonar os limites da uilla (I, 8, 6) nem fazer qualquer negócio por conta própria (I, 8, 13). Sua função é zelar exclusivamente pelos interesses do senhor, cuidando tanto dos equipamentos da uilla (I, 8, 8) como principalmente da escravaria (XI, 1, 21-22). É certo que é um escravo, mas está acima dos demais escravos, em uma posição de comando seja na atribuição de tarefas (XI, 1,7) seja ao servir de exemplo de trabalhador:

Convém que o capataz cuide para que os escravos saiam logo ao raiar do dia não de uma forma vagarosa e preguiçosa, mas, como numa batalha, com vigor e disposição de ânimo, seguindo-o diligentemente como a um comandante, e ele deve exortá-los enquanto trabalham e, de quando em quando, para ajudar alguém extenuado, deve ele mesmo pegar o instrumento e realizar o serviço lembrando-lhe que deve ser feito do modo vigoroso como ele está realizando. (XI, 1, 17)

Significativo nessa passagem é a comparação do uilicus a um dux, a um comandante de exércitos, sugerindo assim um modelo militar de organização da propriedade. De fato, já se mencionou que a uilla columeliana assemelha-se a um esquema de caserna ${ }^{21}$. Embora, em um plano estritamente administrativo, a metáfora seja válida - mesmo porque Columela serviu como legado em legiões na Síria - , a questão do poder na uilla descrita por Columela não se resume à transposição de uma hierarquia militar para a diferen- 
ciação dos trabalhadores agrícolas. A nosso ver, e será este o ponto abordado doravante, o tratado de Columela incorpora debates políticos mais amplos que tinham lugar no principado neroniano e cujo tema principal era a autoridade imperial e seu modo de se postar diante da aristocracia. Não por acaso o problema da legitimação do poder é central para a reflexão de Columela sobre os papéis do uilicus e do proprietário. Nesse sentido, quando se põe a discorrer sobre o perfil ideal do uilicus, Columela expressa as recomendações a respeito de como o uilicus deve manifestar sua autoridade de uma forma semelhante às visões de Sêneca sobre o poder imperial e o poder do senhor de escravos. Escreve Columela:

[O capataz] deverá considerar o que é difícil de se observar mesmo no tocante aos maiores poderes, isto é, não agir de forma muito cruel ou indolente com os subordinados; é preciso sempre incentivar os bons e empenhados, poupar os menos aptos, e agir moderadamente para que eles mais respeitem sua severidade do que odeiem sua crueldade. E poderá obter isso se preferir cuidar para que um trabalhador não erre do que, se errar, puni-lo. Pois não há nada mais eficaz para controlar o pior dos homens do que retirar-lhe dia a dia suas tarefas. (XI, 1, 25) $)^{22}$

A frase inicial desta passagem indica que Columela pensa no poder do uilicus em termos macroscópicos, isto é, tendo em vista formas públicas de poder, e não seria demasiado arriscado afirmar que se trata de uma referência ao poder imperial. Isso fica mais claro se compararmos as idéias do texto acima com aquelas expressas por Sêneca no seu tratado De Clementia, dirigido a Nero no início de seu governo, e em sua carta 47 a seu amigo Lucílio. Nesses textos o filósofo advoga uma autoridade, seja do princeps seja do dominus, baseada não na crueldade gratuita mas na idéia de clemência, ou melhor, governar mediante o recurso à suspensão de penalidades diante dos delitos cometidos, pois apenas assim os subalternos tornam-se gratos e não se voltam mais contra o governante. O recorrente uso da violência, pelo contrário, apenas faz crescer a revolta contra a autoridade constituída. Tanto maior será a autoridade quanto menor for o recurso às suas prerrogativas, sobretudo àquela do direito de vida e morte sobre os governados.

Este princípio político é transferido por Columela para a uilla, e não apenas no tocante ao uilicus, mas também ao proprietário:

O capataz deve observar dois pontos fundamentais: não tirar as algemas de ninguém a quem o dono tenha destinado algum castigo, a não ser que tenha sido autorizado, e não libertar ninguém que ele mesmo haja acorrentado antes que o senhor conheça as circunstâncias; e o senhor da casa deve tomar um cuidado particular com estes escravos, para que não sejam tratados injustamente com re- 
lação a suas roupas ou em outros benefícios. Pois os escravos estando submetidos a um grande número de pessoas - o capataz, os supervisores e os carcereiros - podem facilmente sofrer uma punição injusta. E então, prejudicados pela crueldade e ambição, tornam-se mais perigosos. Assim um senhor cuidadoso inquirirá sobre eles e também sobre os escravos não acorrentados, pois estes são mais dignos de crédito, se estão recebendo o que lhes é devido segundo o que ordenará. [...] Ele deve dar também oportunidade de queixar-se daquelas pessoas que os tratam mal ou com crueldade. Com efeito, eu às vezes defendo aqueles que têm uma justa causa de queixa e puno aqueles que incitam os escravos à revolta ou que caluniam seus supervisores; por outro lado, recompenso aqueles que se comportam com energia e diligência. [...] Agindo com tal justiça e consideração, o senhor muito contribui para o crescimento de seu patrimônio. (I, 8, 17-20)

Nessa apresentação das relações escravistas na uilla observa-se, em primeiro lugar, que o proprietário não considera os escravos exclusivamente como mercadorias, o que representa um claro contraste com Catão e Varrão, em cujas obras os escravos são rebaixados ao status de simples instrumentos, passíveis de serem descartados quando necessário ${ }^{23}$. Isso não significa que Columela desconsiderasse os escravos como propriedade, mas que sua conduta perante eles era pautada também por outros princípios. O paterfamilias surge em sua descrição como um apaziguador dos conflitos que porventura despontem dentro da escravaria devido à desigual posição dos escravos na uilla. Tendo delegado poderes administrativos ao uilicus, cabe-lhe averiguar se suas prescrições são levadas a cabo. Temos aqui então um modelo descentralizado de gestão, que possibilita que todas as tensões recaiam diretamente sobre o administrador direto, o uilicus, poupando a figura do proprietário que parece pairar acima de quaisquer conflitos. Que tal modelo de gestão tenha um equivalente público, Columela diz explicitamente em outra passagem:

Após tudo isso ter sido realizado, não julgo que a distribuição tenha resultados a não ser, como disse, se geralmente o capataz, e também de vez em quando o senhor ou a senhora inspecionem e cuidem para que o que foi ordenado seja executado. Isto é sempre observado nas cidades de bons costumes, onde os primeiros e melhores não se satisfazem apenas em ter boas leis, mas escolhem dentre os mais diligentes cidadãos aqueles que os gregos chamam de "guardiões das leis" [nomophúlakes]. Cabia-lhes atribuir aos que obedeciam as leis louvor e outras distinções, e, aos que não obedeciam, castigar com penas. Isto agora cabe aos magistrados, guardiões da força da lei por uma constante administração da justiça. (XII, 3, 10-11) 
Columela já comparara o proprietário da uilla a um imperator ${ }^{24}$, uma titulação militar. Agora o proprietário aparece com um verniz civil como um guardião das leis (nomophulax). Apesar desse trecho ser uma derivação direta do Econômico de Xenofonte ${ }^{25}$, o fato de Columela servir-se da tradição filosófica grega sobre as analogias entre o oikos e a polis explica-se também por ela permitir-lhe considerar aspectos específicos da conjuntura sob a qual escreve, isto é, o principado de Nero. Portanto, é à luz dessa conjuntura que se deve compreender o modelo de gestão esboçado por Columela, e que diz respeito à preocupação em apresentar o proprietário como o governante de um Estado em ponto pequeno, como sugerem os termos imperator e nomophulax.

Se retomarmos as reflexões de Columela no prefácio de seu tratado, quando compara as aristocracias republicana e imperial, vê-se que a diferença fundamental entre elas é que a primeira tinha uma clara função política militar, enquanto a segunda é apresentada como ociosa (I, Praef., 13-15), sugerindo assim uma desmilitarização da elite romana sob o Principado, um fenômeno que aliás modificou a visão de mundo da aristocracia ${ }^{26}$. Escrevendo para uma elite agora sem função militar e sob a égide do imperador em Roma, Columela desenha sua uilla ideal como um reflexo invertido dessa sociedade, no sentido de que em sua propriedade rural o aristocrata usufruísse um prestígio político e militar que lhe era negado na esfera pública. Por sua vez, o relacionamento entre proprietário e escravos é apresentado como uma imagem especular da relação entre imperador e senado em Roma. Assim como o dominus deve na uilla buscar dirimir a rivalidade no interior da escravaria devido à desigual distribuição de competências - por meio de uma intervenção indireta, deixando ao uilicus o ônus de um embate direto, o imperador em Roma deve ficar acima das disputas políticas da aristocracia senatorial, intervindo como um apaziguador e defensor das leis.

Essa imagem pode ser depreendida da narrativa de Tácito nos Anais, acerca do período neroniano, onde vemos um Nero respeitador das tradições e das leis, e fazendo valer sua vontade perante um senado dividido por posições políticas divergentes. Um primeiro episódio que ilustra isso se situa em 56 d.C.. Nesse momento, ocorreu um debate, no conselho imperial, a respeito de uma decisão do Senado de conceder aos patronos o direito de revogar a liberdade dos libertos (Ann., XIII, 26-27). Segundo Tácito, tendo os senadores concordado com a proposta de revogação de liberdade, os cônsules não ousaram iniciar a votação e remeteram a decisão do Senado ao imperador. Seu conselho privado dividiu-se quanto à proposta. Um grupo defendeu a medida, argumentando que apenas o medo de punição levaria os libertos a obedecerem a seus patronos. Outros, contudo, discordaram, afirmando que não se deveria promulgar uma lei geral e que cabia aos patronos avaliar os méritos dos escravos antes de manumiti-los. Essa posição prevaleceu, e Nero 
ordenou que nenhuma lei geral fosse estabelecida e se julgasse cada caso em particular. $\mathrm{O}$ argumento que se impôs enfatizava que os libertos e seus descendentes estavam inseridos na estrutura social e política da cidade. Portanto, nesse embate, a noção de tradição, do mos maiorum como princípio norteador da política romana, prevaleceu com o apoio do imperador.

Esse ponto reaparece no episódio do assassinato de Pedânio Secundo, prefeito da cidade de Roma, por um de seus escravos, em 61 d.C. (Ann., XIV, 42-45). Diante desse acontecimento, novamente criou-se uma turbulência no Senado pois, a seguir-se um decreto senatorial que remontava à época de Augusto, todos os escravos da casa deviam pagar com a vida o crime cometido por um deles ${ }^{27}$. No caso, isso implicava a execução sumária de quatrocentos escravos. Parte dos senadores mostrou-se relutante, mas Tácito transcreve somente o discurso de Caio Cássio, que defendia a pena de morte. Eis a conclusão de sua longa fala:

Nossos antepassados não confiavam na lealdade dos escravos, ainda mesmo dos nascidos em suas propriedades e em suas casas, criados no afeto dos senhores. Hoje que temos em nossas famílias servis pessoas de nações diversas, de vários ritos, de religiões diferentes ou de nenhuma, só o medo pode ser coerção para esse entulho. Objetar-se-á que muitos morrerão inocentes. Sim, mas quando se dizima um exército e cada décimo soldado é castigado, também os valorosos são sorteados. Todos os grandes exemplos trazem consigo alguma iniqüidade contra indivíduos, porém, esta redunda em utilidade pública. (Ann., XIV, 44)

No entanto, já aceita essa decisão, um senador defendeu ainda que se incluíssem os libertos de Pedânio, o que provocou uma reação de Nero, que se mostrou contrário, afirmando que "um costume antigo que não foi abrandado pela misericórdia, não poderia ser agravado pela severidade" (Ann., XIV, 45). Novamente, então, Nero aparece como defensor da tradiçã $0^{28}$. Nesse contexto, o termo nomophulax utilizado por Columela para qualificar o proprietário da uilla não deixa de ter uma clara conotação política.

\section{CONCLUSÃO}

Pelo tratamento que confere ao espaço e à escravidão na uilla, Columela distancia-se consideravelmente da tradição agronômica que lhe antecede, ou pelo menos de Catão e Varrão. Embora estes mencionem ambos os temas, o fazem de uma maneira bem mais sintética; com relação aos escravos, a margem amplia-se ainda mais. Catão, escrevendo por volta de 160 a.C., e Varrão, por volta de 37 a.C., apresentam o escravo de uma maneira próxima àquela 
jurídica que o qualifica como uma coisa (res). Por conseguinte, não se delongam em descrever as relações pessoais entre o proprietário e sua escravaria como faz Columela. Essa mudança de posicionamento não é apenas de ordem econômica - alto custo dos escravos devido ao fim das guerras de conquista a partir do século I d.C. - , mas de ordem política, uma vez que remete a transformações na composição e função da aristocracia romana, o que não deixou de ter seus reflexos na organização do espaço e do poder na uilla.

Tais transformações referem-se ao próprio processo de transição da República para o Principado, quando ocorreu uma redistribuição de poder e autoridade no seio da aristocracia. Enquanto no período republicano os aristocratas detinham e competiam entre si por posições de poder no governo, por meio de um sistema oligárquico de magistraturas anuais, com o advento do Principado o poder concentrou-se no imperador e em pessoas próximas a ele, muitas vezes senadores e cavaleiros, mas também libertos da casa imperial. Por seu turno, a distribuição de cargos políticos e militares passava agora por redes de clientela que tinham no topo o imperador. Esse processo de transição política foi acompanhado por outro de cunho conceitual, sendo recentemente denominado por Matthew Roller de "construção da autocracia"29, no sentido de que a aristocracia júlio-cláudia, que assistiu à montagem e consolidação do sistema imperial, buscou formular um aparato conceitual que lhe permitisse não apenas compreender a estrutura de poder que surgia, mas principalmente negociar a distribuição de poder e prestígio. Daí a preocupação da literatura da época em formular uma nova ética de participação política e apresentar ao imperador modelos de conduta que tinham como parâmetros figuras de autoridade como pater e dominus.

Embora ainda não tenha sido analisada sob esse prisma, a obra de Columela respalda tal interpretação, revelando que o dito processo de "construção da autocracia" no período júlio-cláudio não se restringiu apenas à esfera da política mas atingiu também, mesmo que no nível do discurso, as práticas de gestão escravista e a configuração espacial das uillae no mundo rural italiano.

\section{NOTAS}

* Este artigo é resultado de pesquisa de doutorado desenvolvida no Departamento de História - FFLCH-USP sob orientação do Prof. Dr. Norberto Luiz Guarinello e com financiamento da FAPESP. Sou grato aos professores Norberto Luiz Guarinello, Maria Beatriz Borba Florenzano, Rafael de Bivar Marquese e Fábio Faversani pela leitura do texto.

${ }^{1}$ LESSING, Gotthold Ephraim. Laocoonte ou sobre as fronteiras da pintura e da poesia. Introdução, tradução e notas de Márcio Seligmann-Silva. São Paulo: Editora Iluminuras, 1998, p. 75. 
${ }^{2}$ MARQUESE, Rafael de Bivar. Administração \& escravidão: idéias sobre a gestão da agricultura escravista brasileira. São Paulo: Hucitec, 1999, p. 56. Ver também, a esse respeito, SCHUMPETER, Joseph. History of economic analysis. Londres: Routledge, 1994, p. 157.

${ }^{3}$ GRIFFIN, Miriam. Seneca, a philosopher in politics. Oxford: Oxford University Press, 1976, pp. 89, 290-291.

${ }^{4}$ L. IVNIO L. GAL / MODERATO / COLUMELLAE / TRIB. MIL. LEG. VI FERRATAE. (CIL IX 235).

${ }^{5}$ MARTIN, René. État présent des études sur Columelle. Aufstieg und Niedergang der römischen Welt, II.32.3, 1985, p. 1.962.

${ }^{6}$ GUMMERUS, Herman. Der römische Gutsbetrieb als wirtschaftlicher Organismus nach den Werken des Cato, Varro und Columella. Aalen: Scientia Verlag, 1979 (Klio — Beiträge zur Alten Geschichte, Beiheft 5). Inicialmente publicado em 1906.

${ }^{7}$ Sobre a questão do trabalho, ver, por exemplo, GARNSEY, Peter. Non-slave labour in the Roman world. In: GARNSEY, Peter. Cities, peasants and food in classical Antiquity: Essays in social and economic history. Edited with addenda by Walter Scheidel. Cambridge: Cambridge University Press, 1998, pp. 134-150.

${ }^{8}$ GUMMERUS, Herman. Op. cit., pp. 94-95.

${ }^{9}$ WEBER, Max. Storia economica e sociale dell'Antichità: i rapporti agrari. Roma: Editori Riuniti, 1992, pp. 22-23, 310.

${ }^{10}$ WEBER, Max. História geral da economia. São Paulo: Editora Mestre Jou, 1968, p. 251. Cabe notar que Weber não descarta por completo a possibilidade de uma racionalidade econômica na agricultura com uso do trabalho escravo, mas salienta que esta só se realiza na presença de condições específicas, sendo a guerra a principal delas. A expansão militar gerava uma maior disponibilidade de escravos e incentivava seu uso capitalista em plantações, empresas marítimas, mineração, ergasteria, etc. A existência de terras a baixo custo, muitas vezes resultado de guerras, também era uma condição essencial pois compensava o alto investimento realizado na compra da escravaria e o capital nela imobilizado (WEBER, Max. Storia economica e sociale dell'Antichità: i rapporti agrari. Roma: Editori Riuniti, 1992, p. 30). Aliás, já em seu ensaio de 1896 sobre o declínio da cultura antiga (Die sozialen Gründe des Untergangs der antiken Kultur), Weber afirmava que o mundo antigo perdurou enquanto se manteve um fluxo constante de escravos, por meio de guerras, possibilitando assim uma mão-de-obra barata. Os outros fatores que levaram à sua derrocada - a crescente insuficiência do exército, a burocratização do Estado imperial romano e o deslocamento do eixo cultural das cidades para o campo - aparecem antes como reflexos do fim da escravidão (cf. LOVE, John. Antiquity and capitalism: Max Weber and the sociological foundations of Roman civilization. Londres: Routledge, 1991, p. 30). Sobre a visão weberiana da Antigüidade tivemos oportunidade de tratar em outro artigo: JOLY, Fábio D. Capitalismo e burocracia: economia e política nas Relações agrárias na Antigüidade, de Max Weber. Revista de História, FFLCH/USP, 140, 1999, pp. 9-22. 
Fábio Duarte Joly

${ }^{11}$ GARNSEY, Peter e SALLER, Richard. The Roman empire: economy, society and culture. Londres: Duckworth, 1987.

${ }^{12}$ FINLEY, Moses. I. A economia antiga. Porto: Afrontamento, 1986, pp. 158-159.

${ }^{13}$ GUARINELLO, Norberto L. A economia antiga e a arqueologia rural: algumas reflexões. Clássica. São Paulo, 7/8, 1994/1995, p. 273.

${ }^{14}$ CARANDINI, Andrea. Columella's vineyard and the rationality of Roman economy. Opus, 2, 1, 1983, p. 192.

${ }^{15}$ CARANDINI, Andrea. L'economia italica fra tarda Reppublica e Medio Impero considerata dal punto di vista di una merce: il vino. In: AA. VV., Amphores romaines et histoire économique: dix ans de recherche. Roma: École Française de Rome, 1989, pp. 514-516. Carandini retoma aqui considerações já formuladas por Michael Rostovtzeff (ROSTOVZEFF, Michael. The social and economic history of the Roman empire. Oxford: Clarendon Press, 1966, pp. 98-99).

${ }^{16}$ MARTIN, René. Recherches sur les agronomes latins et leurs conceptions économiques et sociales. Paris: Les Belles Lettres, 1971, pp. 311-342.

${ }^{17} \mathrm{O}$ texto de Columella aqui adotado é o da Loeb Classical Library. As traduções são de minha responsabilidade.

18 "Como tratamos dos planos, tendo em vista a disposição dos aposentos, devemos, agora, considerar como, em edifícios privados, os cômodos dos patrões e das visitas devem ser edificados. Os aposentos privados não podem ser acessíveis sem um convite, como os quartos de dormir, triclinia, banhos e outros locais com funções semelhantes. Os aposentos comuns são aqueles aos quais o povo pode, de pleno direito, ir, como os vestíbulos, pátios, peristilos e outros desse tipo. Assim, magníficos vestíbulos e aposentos e átrios não são necessários para as pessoas de fortuna comum, pois visitam, mas não são visitados." (De Architectura, VI, 5). Trad. de Pedro Paulo A. Funari (FUNARI, Pedro Paulo A. Antigüidade Clássica: a história e a cultura a partir dos documentos. Campinas: Editora da Unicamp, 1995, p. 116).

${ }^{19}$ MARTIN, René. Op. cit., p. 368.

${ }^{20}$ MARTIN, René. Familia Rustica: les esclaves chez les agronomes latins. Annales Littéraires de l'Université de Besançon, 163, 1974, pp. 270-271.

${ }^{21}$ Idem, p. 285.

${ }^{22}$ Cf. também I, 9, 10.

${ }^{23}$ "Faça um leilão: venda o azeite, se o preço for bom, vinho, o trigo que sobrou, os bois velhos, gado em mal estado, lã, couro, carro velho, ferramentas velhas, os escravos velhos ou doentes e tudo o que sobrar, venda; o senhor deve ser um vendedor e não um comprador." (Catão, De Agri Cultura, II, 7); "Falarei agora daquelas coisas com as quais cultivamos uma fazenda. Alguns as dividem em duas partes, os homens e os instrumentos de trabalho, sem 
os quais não se pode cultivar. Outros em três partes: instrumentos vocais, semivocais e mudos. Os que têm voz, como os escravos, os semivocais, como os bois, e os mudos, como os carros." (Varrão, Rerum Rusticarum, I, 17, 1).

${ }^{24}$ Cf. I, $1,18$.

${ }^{25}$ Nessa obra, em determinado momento o personagem Iscômaco diz a Sócrates: "Expliquei-lhe [à sua esposa] que, na minha opinião, aos cidadãos não basta que tenham boas leis. Ao contrário, elegem guardiões da lei que, mantendo a vigilância, elogiam os que cumprem as leis, mas punem, se alguém age contra elas. Portanto, aconselhei minha mulher, disse ele, a ser a guardiã das leis de nossa casa e a passar em revista, quando lhe parecesse bem, os objetos de casa como o comandante de uma guarnição passa em revista os guardas e os examina para ver se cada um está bem" (Econ., IX, 15). Cf. XENOFONTE. Econômico. Tradução do grego e introdução de Anna Lia Amaral de Almeida Prado. São Paulo: Martins Fontes, 1999.

${ }^{26}$ CORNELL, Tim. The end of Roman imperial expansion. In: RICH, John e SHIPLEY, Graham (eds.), War and society in the Roman world. Londres: Routledge, 1993, pp. 164-165.

${ }^{27}$ Trata-se do senatus consultum Silanianum, de 10 d.C.. A seu respeito, consultar BOULVERT, G. e MORABITO, M. Le droit de l'esclavage sous le Haut-Empire. Aufstieg und Niedergang der römischen Welt, II.14, 1982, pp. 107-108.

${ }^{28}$ Mas cabe observar que em momento algum Tácito elogia abertamente essa questão, como que deixando ao leitor que julgue por si próprio a conduta política de Nero. Ao construir sua narrativa realçando apenas aqueles aspectos que lhe interessava criticar, permitiu que se construísse uma memória negativa de Nero que, nos séculos seguintes, uma leitura superficial de sua obra acabaria por sedimentar.

${ }^{29}$ ROLLER, Matthew. Constructing autocracy: aristocrats and emperors in Julio-Claudian Rome. Princeton: Princeton University Press, 2001, pp. 7-8.

Artigo recebido em 1/2003. Aprovado em 4/2003. 